GSI Journals Serie A: Advancements in Tourism, Recreation and Sports Sciences

(GSI Dergileri Seri A: Turizm, Rekreasyon ve Spor Bilimlerindeki Gelişmeler)

ATRSS 2022, 5 (1): 27-43 - Research Article/Araştırma Makalesi - Received/Geliş T.: 08.01.2022 - Published/Kabul T.: 15.02.2022

\title{
Akarsu Koridorlarında Akustik Konforun Değerlendirilmesinde İşitsel Peyzajın Rolü, Ayvalı Dere Örneği
}

Hatice Oya EŞBAH, Bursa Teknik Üniversitesi, Orman Fakültesi, Peyzaj Mimarlığı Bölümü, hatice.esbah@btu.edu.tr, Bursa, Türkiye, ORCID: 0000-0002-6035-990X

Sara DEMIR, Bursa Teknik Üniversitesi, Orman Fakültesi, Peyzaj Mimarlığı Bölümü, sara.demir@btu.edu.tr, Bursa, Türkiye, ORCID: 0000-0002-0813-3356

Yalçın YILDIRIM, Bursa Teknik Üniversitesi, Orman Fakültesi, Peyzaj Mimarlığı Bölümü, yalcin.yildirim@btu.edu.tr, Bursa, Türkiye, ORCID: 0000-0002-3556-088X

Öz

Akarsu koridorları, kentin gürültülü ve stresli ortamından kentlileri uzaklaştırarak huzur ile dinlenmelerini sağlayan rekreasyonel hizmetler sunmaktadır. Dolayısıyla bu mekanlardaki gürültü kaynaklarının belirlenmesi ve daha sonra doğallyapay çözümler sunulması işitsel peyzajın amaçlarından biridir. Çalı̧̧ma kapsamında Bursa'nın Nilüfer ilçesinden geçen kent, sanayi ve tarım baskısı altında olan Ayvalı Dere ve çeoresi ele alınmış ve kentin rahatsız edici ve istenmeyen sesleri uzaklaştıran ve doğal seslere odaklanmayı să̆layan tasarım ve mühendislik hizmetlerinin önerilmesi amaçlanmıştır. Bu amaca ulaşmak için işitsel peyzajı ile ilgili Dünya'da ve Türkiye'de gerçekleşmiş olan araştırmalar ve projeler irdelenmiştir ve birbirleri ile karşılaştırlmıştır. Sonuç olarak, gürültüyü filtreleyen ve istenilen seslere vurgu sağlayan çözümler üreten ve fiziksel, fizyolojik ve sosyolojik etkileşim sağlayan akustik konfor kriterleri incelenmiştir. Bu kapsamda çalışma alanı çevresinde su, ses duvarı, bitki materyali, kentsel donatı kullanımları önerilmiştir. Böylece tarım, yerleşim ve sanayi alanından geçen ve kentliye doğal bir ortam sağlayan Ayvah Dere ve çevresinde işitsel peyzaj kavramı kapsamında su çevresinde akustik konfor sağlayan çözüm önerileri geliştirilmiştir Bunun için seslerin analizinde gürültü ölçüm aracı olan OKTAVA 110A-PRO ile kalibre edilmiş olan "dB meter lite" adlı ses ölçümü yapan telefon uygulamasından yararlanılmıştır.

Anahtar Kelimeler: Su koridorlarl, kentsel baskl, akustik ekoloji, işitsel peyzaj, gürültü kirliliği

\section{The Role of Auditory Landscape in Evaluation of Acoustic Comfort in Stream Corridors, Ayvalı Dere Sample}

\begin{abstract}
Stream corridors keep the citizens away from the noisy and stressful environment of the city and allow them to rest in peacefully. Thus identifying the noise sources and providing natural/artificial solutions is one of the purposes of the soundscape. The aim of this study is to, Ayval Stream passing through the Nilüfer district of Bursa, and its surroundings, which are under the pressure of industry and agriculture, to propose the design and engineering services of the city that remove the disturbing and unwanted sounds and focus on natural sounds. To reach of this aim, the researches and projects that have been carried out in the world and in Turkey regarding the soundscape have been examined and compared with each other. As a result, the use of water, sound barrier, plant material and urban reinforcement has been suggested around the study area that provide acoustic comfort around Ayval, Stream, which passes through the agricultural, settlements and industrial areas. For this purpose, a noise measurement of phone application called "dB meter lite", calibrated with OKTAVA 110A-PRO, was used to measure the sounds.
\end{abstract}

Keywords: Water corridors, urban pressure, acoustic ecology, soundscape, noise pollution

*Bu çalışma, TR Dizin etik kurul izni gerektiren çalışma grubunda yer almamaktadır. 


\section{Giriş}

Beş duyumuzdan biri olan sesleri işitme eylemi, önemli bir iletişim aracıdır. Bu sebeple ses frekanslarının değişmesi insanların ruhsal ve fiziksel sağlıkları üzerinde önemli etki bıraktığı tespit edilmiştir. Yüksek ses seviyelerinin insan sağlığı üzerinde olumsuz etkileri olduğunu belirten Dünya Sağlık Örgütü'nün (WHO) açıklamasına göre $65 \mathrm{~dB}(\mathrm{~A})^{\prime}$ in üstündeki sesler insanlarda bir süre sonra duyma kaybından dikkat dağınıklığına kadar birçok fiziksel ve psikolojik problemlere neden olmaktadır (WTO, 1999; Bayraktar, 2006; Özdemir vd., 2014). Bu noktada gürültü ise özellikle birçok insan kaynaklı eylemlerden ortaya çıkan ve insan sağlı̆̆ını pek çok açıdan etkileyen istenmeyen ses biçimi olarak tanımlanabilir (Demirkale \& Aşcıgil, 2007; Bayramoğlu vd., 2014; Radicchi vd., 2021).

2050 yılında kentlerde \%68'i yaşanması tahmin edilen dünya nüfusunun günümüzde \%55'inin kentlerde yaşamaya başlaması, teknoloji ile hızla büyüyen endüstrileşme, ulaşım ağlarının yoğunlaşması paralelinde araç kullanımının artması, sesi iletişim aracı olmaktan çıkarıp insan sağlığını etkileyen önemli bir gürültü kaynağı haline dönüştürmektedir. Özellikle kentlerin daha çok maruz kaldığ1 ve gürültü kirliliğine yol açan bu gürültü kaynağının planlama ve tasarım ölçeğinde çözümü son yıllarda işitsel peyzaj kavramını gündeme getirmiştir. Dünya Sağlık Örgütüne göre; trafik kaynaklı gürültü kirliliğinin olumsuz etkisinin insan sağlı̆̆ üzerinde oldukça etkin olduğu tespit edilmiştir (WHO, 1999; Bayramoğlu vd., 2014; Schulte-Fortkamp \& Brooks, 2018). Özellikle insan sağlığı üzerinde kalıcı etkiler bırakan gürültü kirliliğinin sınırı, kentsel ve kırsal alanlarda farklılık gösterdiği gibi kentsel alanlardaki kullanımların değişmesi ile birlikte de farklılaşmaktadır.

Fizyolojik, psikolojik ve performans etkileri olan gürültü, beş farklı derecede sınıflandırılmıştır (Demirkale \& Aşcıgil, 2007; Özdemir vd., 2014; Pouya, 2017). 30-65 dB(A) ses değerleri arasında oluşan 1. derecede gürültüler rahatsızlık, konfor kaybı, konsantrasyon ve uyku bozukluğuna sebep olmakta, 65-90 $\mathrm{dB}(\mathrm{A})$ ses değerleri arasında oluşan 2. derece fizyolojik gürültüler; kalp ritminin ve solunum hızının artmasına, beyindeki basıncın azalmasına, 90-120 dB(A) arası 3. derece gürültü, 120-140 dB(A) arası 4 . derece gürültü ve $140 \mathrm{~dB}(\mathrm{~A})$ üstü ses değerleri ise 5 . derece gürültü olarak baş ağrısı, iç kulak bozuklukları ve kulak zarının patlamasına sebep olmaktadır. Bu bağlamda gürültü kirliliğinin toplum sağlığı üzerindeki etkisini kontrol altına alabilmek için ülkeler tarafından kendi yasal yönetmelik ve mevzuatlarında düzenlemeler yapılmış ve her farklı kullanıma yönelik farklı ses ölçümlerinin sınırı belirlenmiştir. Özellikle birçok ülkede gürültü kirliliğin temel sorularından biri olarak kabul edilen ulaşım kaynaklı kirlilik için üst sınır ses ölçümleri belirlenmiştir. Türkiye'de kabul edilen Çevresel Gürültünün Değerlendirilmesi ve Yönetimi Yönetmeliği'ne (ÇGDYY) göre, kırsal alanlardaki yollarda gündüz 55 $\mathrm{dB}(\mathrm{A})$, eğitim, kültür ve sağlık alanlarında $60 \mathrm{~dB}(\mathrm{~A})$, yerleşim alanlarında $63 \mathrm{~dB}(\mathrm{~A})$, yerleşim ve ticaret odaklı alanlarda $65 \mathrm{~dB}(\mathrm{~A})$ ve endüstriyel alanlarda $67 \mathrm{~dB}(\mathrm{~A})$ üst sınır ses ölçümü dikkate alınmaktadır (Demirkale \& Aşcigil, 2007; Bayramoğlu vd., 2014). Türkiye'de kabul edilen bu yönetmeliği'ne göre karayolları çevresinde gündüz alınan ses ölçümlerinin $60 \mathrm{~dB}(\mathrm{~A})$ sınırını aşmaması gerektiği belirlenmiştir. Aynı yönetmelikte, yerleşim alanları çevresinde $55 \mathrm{~dB}(\mathrm{~A})$ sınırının altındaki gürültü dikkate alınmamakta, $64 \mathrm{~dB}(\mathrm{~A})$ sınırına kadar gürültü için fiziksel önlemler alınması gerekmektedir.

Güncel trendlerle birlikte sürekli olarak gelişen ve değişen günümüz kentleri gün geçtikçe genişlemekte ve kentsel alanların kırsal alanlara oranı da benzer sebeplerden dolayı artmaktadır. Sanayi devriminden itibaren hız kazanan bu kentleşme süreci, birçok kentsel ve çevresel sorunların da başlangıcına sebep olmuştur. Gürültü kirliliği de bu kentsel sorunlardan biridir. Gürültü kirliliği özet bir şekilde istenmeyen ses anlamına gelmektedir. Gün içerisinde bu seslere sürekli maruz kalmak insanların yaşam kalitesini ve sağlığını etkilemektedir. Kent içerisinde gürültü kirliliğine çözüm olarak açık yeşil alanlar gösterilmektedir. Ancak yeşil alanlar planlanırken ve tasarlanırken işitsel peyzaj olgusu yeteri kadar dikkate alınmamaktadır. İşitsel peyzajı, daha detaylı olarak tanımlamak gerekirse, akustik ekolojinin kapsamındadır ve endüstriyel teknolojinin kullanımından kaynaklanan mekanik kökenli sesler dahil olmak üzere hayvanlar, ağaçlardan gelen sesler olan doğal seslerden, su seslerinden, hava seslerinden ve müzikal kompozisyon, ses tasarımı ve diğer yollarla insanlar tarafından yaratılan çevresel seslerden oluşan doğal akustik ortamı ifade etmektedir (Han vd., 2018). İşitsel peyzajların temel amacı gürültü 
kirliliğinin olduğu alanları, alanın karakterini yansıtarak ve kirliliğin önüne geçerek yeniden kullanıcıyla birleştirmektedir. Bunun yanında dinleyici için bir mekan oluşturmak, kent içerisinde yaşam kalitesini artırmak, kentsel ısı adasının etkisini azaltmak, insanları yeşil alanları kullanmaya teşvik etmek, turizme ve ekonomiye katkı sağlamak gibi amaçları bulunmaktadır (Stevens, 2010; Brown, 2011; Kang, 2011).

Doğal ve kültürel peyzajlarda olumlu-olumsuz etki yaratan ses kaynakları ve bu ses kaynaklarının birbirleri arasındaki fiziksel, fizyolojik ve sosyolojik etkileşimleri ve bu etkileşimlerin canlılar üzerindeki etkisi akustik peyzajı oluşturmaktadır (Özçevik \& Can, 2011; Kaymaz vd., 2013). İnsanların bulundukları ortamlardan rahatsız edici ve hoş olmayan seslerin uzaklaştırılmasını sağlamak akustik konforun temel koşuludur. Akustik konforun işitsel peyzaj alanında rolü belirlenirken gürültüden kaynaklanan fizyolojik rahatsızlık ve çalışma alanının kendine özgü seslerinin de dikkate alınması gerekmektedir (Özçevik \& Can, 2011; Kaymaz vd., 2013). Özellikle kentsel peyzajlarda akustik kalitenin artırılmasına yönelik kentte gürültüye neden olan etkenler tespit edilmekte ve onları izole eden bitkisel ve yapısal tasarım önerileri geliştirilmektedir. İşitsel peyzaj kavramı, peyzaj mimarlığı çalışmalarında son yıllarda önem kazanmakta ve tasarım süreçlerine entegre edilmektedir. Bu bağlamda akustik konfor ile çalışma alanına kendisine has bir işitsel peyzaj karakteristiklerinin kazandırılması alanın tercih edilebilirliği ve tanınabilirliği açısından oldukça etkilidir.

Kentlerde önemli bir tatlı su kaynağı olan akarsu koridorları iyi planlandığı sürece kentin gürültülü ve stresli ortamından kentlileri uzaklaştırarak doğa seslerinin içinde huzur ile dinlenmelerini sağlamakta, kentte nefes alma boşlukları oluşturarak rekreasyonel hizmetler sunmaktadır. Bu doğal alanlarda doğa seslerini ön plana çıkararak işitsel peyzaj kavramını gündeme getirmektedir. İşitsel peyzaj, belirli bir mekanda insan kulağına ulaşarak algılanan seslerin tümünü kapsamaktadır. Bu ses mekanı tanımlayan bir unsur olarak ele alınmaktadır (Schafer, 1977; Hiramatsu, 2006; Kaymaz vd., 2013). Mekanda akustik konforun sağlanması için insanların bulundukları mekanlardaki rahatsı edici ve istenmeyen seslerin uzaklaştırılması gerekmektedir (Hiramatsu, 2006; Yıldırım \& Arefi, 2020). Bu mekanlardaki doğal ve yapay birleşenler, ses kaynakları ve bunların birbirleri arasındaki fiziksel, fizyolojik ve sosyolojik ilişki, algılanan akustik konforu oluşturur (Özçevik \& Can, 2010; Radicchi vd., 2021). Doğadan gelen seslerin ortak özelliği insanların bu sesleri rahatlatıcı ve huzur verici bulmasıdır. Dolayısıyla doğayı anımsatacak seslerin hastane bahçelerinde, açık yeşil alanlarda ve rekreasyon alanlarında özellikle tercih edilmesinde fayda vardır (Özçevik \& Can, 2010; Aslan vd., 2014). Su kaynakları başta kuşlar olmak üzere birçok hayvan türüne ev sahipliği yapmaktadır (Ramsar, 1994). Ayrıca su kaynakları ve bitki örtüsünün zengin olduğu alanların, su öğesi ve bitki örtüsünün daha az olduğu kentsel alanlara göre daha rahatlatıcı etkiye sahip olduğu ve daha az stresli ortamların oluştuğu belirtmiştir (Chiesura, 2004; Tülek \& Barış, 2014).

Bir alanda gürültü kontrolünün sağlanması; kaynak kontrolü, kaynak ve alıcı arasındaki iletişim yönetimi ile alıcı korunması olarak üç aşamada gerçekleşmektedir (Hedfors, 2003; Pouya, 2017). Peyzaj tasarımı her ne kadar görsel peyzajı içerse de çevre bilinci görsel biliş dişında akustik bilişi de kapsamaktadır. Bu amaçla son yıllarda kentlerdeki gürültü kirliliğini azaltarak kentsel yeşil alanlardaki ses kalitesini artırmak için işitsel peyzaj kavramı kullanılmaktadır (Pouya 2017). Bu gibi çalışmalar, işitsel peyzajın, peyzaj tasarımındaki rolünü ve önemini vurgulamaktadır. Bu kapsamda Ayvalı Dere boyunca özellikle sanayi ve yerleşimin olduğu bölgelerde su sesini ön plana çıkarmak ve kent ve sanayi gürültüsünü absorbe etmeye yönelik bitkisel tasarımı güçlü peyzaj tasarımı gerçekleştirmek hedeflenmektedir. Böylece derenin geçtiği kentsel yeşil alanlar boyunca işitsel peyzaj ile peyzaj tasarım ilkeleri arasında bir ilişki kurulması planlanmaktadır. Bu bağlamda araştırmada, işitsel peyzaj ile peyzaj tasarım ilkeleri arasındaki ilişki kurabilen önerilerin geliştirilmesi amaçlanmıştır. Bu çalışmada dere boyunca uzanan açık yeşil alanlarda ses kalitesini iyileştirmek için ses tasarımı önerilmektedir. Bu doğrultuda ağaçlar ve çalıların sesi ve gürültüyü emme ve yansitma özellikleri önemli rol oynamaktadır (Pouya, 2017; Han vd., 2018; Oberman vd., 2020). Geniş yeşil kuşakları ve yumuşak zemin tasarımlarının gürültüyü \%50 oranında azalttığ1 veya 30 metre vejetasyon örtüsünün $7 \mathrm{~dB}(\mathrm{~A})$ gürültüyü azalttığı tespit edilmiştir (Pouya, 2017). Kentlerde işitsel peyzaj alanlarının oluşturulması için birçok yöntem vardır. Bunlara örnek olarak; kent içerisinde yeşil zonlar oluşturmak, gürültü bariyerleri kurmak, sesi absorbe eden materyaller tercih etmek ve gürültü 
kirliliğini baskılayıcı su sesi ya da müzik gibi elementler kullanmak gösterilmektedir (Labuz, 2019; Cerwén, 2018; Ağaçsapan \& Çabuk, 2019; Denić-Jukić, 2019; Oberman vd., 2020; Cerwén \& Mossberg,2019; Emilson vd., 2020; Mancini vd., 2021; Radicchi vd., 2021; Han vd., 2018; Bao \& Lu, 2021). Çalışma kapsamında Türkiye' den ve dünyadan işitsel peyzaj kapsamında akustik konfora vurgu yapan ve gürültü üzerinde doğal ve mühendislik çözümleri geliştiren birçok örnek araştırılmıştır. Her bir örneğin gürültü kaynakları incelenmiş ve bu sorunun önüne geçmek amacıyla akustik konfor sağlayan işitsel peyzaj ilkeleri ve tasarım kriterleri üzerinde durulmuştur. Bu çalışma kapsamında, gürültü kaynaklarını tespit etmek amacı ile Ayvalı Dere boyunca ses ölçümleri alınmıştır. Sonuç olarak, araştırılan dünya örneklerinde tespit edilen ve işitsel peyzaja yönelik geliştirilen çözüm önerileri dikkate alınarak Ayvalı Dere için uygun işitsel peyzaj önerileri geliştirilmiştir.

\section{Materyal ve Yöntem}

Bursa ili Nilüfer ilçesinde yürütülen bu araştırmada çalışma alanı olarak, yerleşim bölgesi, organize sanayi bölgesi, arıtma tesisi alanı ve tarım alanların içerisinden geçerek Nilüfer çayına dökülen yapılaşma ve sanayi baskısı altında kirlenen ve suyu azalan Ayvalı Dere ve çevresi belirlenmiştir (Şekil 1). Çalı ve Kayapa derelerinin suyunu toplayan bu dere, Özlüce kanalını geçtikten sonra Özlüce köyü kuzeyinde Ayvalı Dere adını almaktadır. Topoğrafyası, iklimi ve toprak yapısı nedeni ile tarım potansiyeline sahip olan dere çevresinde tarım sektörü temel geçim kaynağ ${ }_{1}$ iken kentsel yayılma ve sanayileşme ile birlikte tarımsal alanlar yerini sanayiye ve yerleşime bırakmıştır. Dolayısı ile dere boyunca tarım, sanayi ve yerleşim üçlüsünün bir arada bulunduğu 3 farklı bölge geçişleri bulunmaktadır. Taşkın alan sınırı korunmamış olan dereye paralel olarak araç yolu geçmektedir. Bu yol kimi yerlerde dereye tam bitişik geçerken kimi yerlerde dere ile yol arasından geçirimli toprak-yeşil zon geçmektedir. Ancak dere, yerleşim alanı ve sanayi bölgesinden geçerken bu araç yollarına dereyi dik kesen trafik yoğunluğu bulanan İzmir yolu gibi araç yolları da eklenmektedir. Araç ulaşımı oldukça etkili olan bu alanda trafik kaynaklı gürültü kirliliği söz konusudur. Derenin ilk aktığı bölgede tarımsal odaklı kırsal alanlar bulunmakta ve dere boyunca dar bir yol uzanmaktadır ve bu yol üzerinde çimento ve mermer fabrikaları bulunması nedeni ile yoğun bir tır geçişine sahiptir. Derenin aktığı ikinci bölge olan İzmir yolunun da geçtiği yerleşim ve sanayi bölgesinde, trafik 1şıklarının bulunduğu durma-kalkma bölgelerinden ve yolların kesişim noktalarından geçen dere ve çevresi, yoğun trafik etkisi altında kalmaktadır. Derenin Nilüfer çayına döküldüğü üçüncü bölgede tarım alanları bulunmakta olup dere boyunca uzanan dar kesitli yolda araç yoğunluğu oldukça azdır. Çevresel Gürültünün Değerlendirilmesi ve Yönetimi Yönetmeliği (ÇGDYY) gereği gündüz 07.00-19.00, akşam 19.00-23.00 ve gece 23.00-07.00 arasındaki zaman dilimleri arasında ses ölçümleri alınmaktadır (Demirkale \& Aşcıgil, 2007). Ancak Karayolları Genel Müdürlüğü (KGM, 2020) 14. Bölge trafik ve ulaşım verilerine göre hafta içi sabah 08.00-10.00 ile akşam 17.00-19.00 saatleri arasında yoğun trafik yoğunluğu olduğu tespit edilmiştir. Bu veriler dikkate alınarak gürültünün en yüksek olduğu bu zaman aralıkları dikkate alınarak ses ölçümleri alınmıştır. İşitsel peyzaj kavramı kapsamında dere koridoru boyunca özellikle dere kollarının ve yolların kesiştiği, trafik ışıklarının ve köprülerin olduğu noktalar ile sportif aktivitelerin ve rekreasyonel aktivitelerin gerçekleştiği alanlardan üçer dakika boyunca alınan ses ölçümleri, OKTAVA 110A-PRO ile kalibre edilmiş olan ve ortalama ses ölçümü ile en yüksek ses ölçümünü (peak level) kaydeden dB meter lite adlı bir telefon uygulaması ile alınmıştır. Bu kapsamda, Dünyada ve Türkiye'de gerçekleşmiş olan mekansal çözümler sunan örnekler araştırılmış ve bu örneklerde işitsel peyzaj kapsamında çalışma alanındaki trafik gürültüsünü absorbe eden ve akustik konfor sağlayan doğal ve yapay tasarım çözümleri incelenmiştir. Bu bağlamda gürültüyü filtreleyen ve su, kuş sesi, yaprak sesi gibi doğal seslere vurgu sağlayan çözümler üreten fiziksel, fizyolojik ve sosyolojik etki yaratan akustik konfor kriterleri dikkate alınmıştır. 


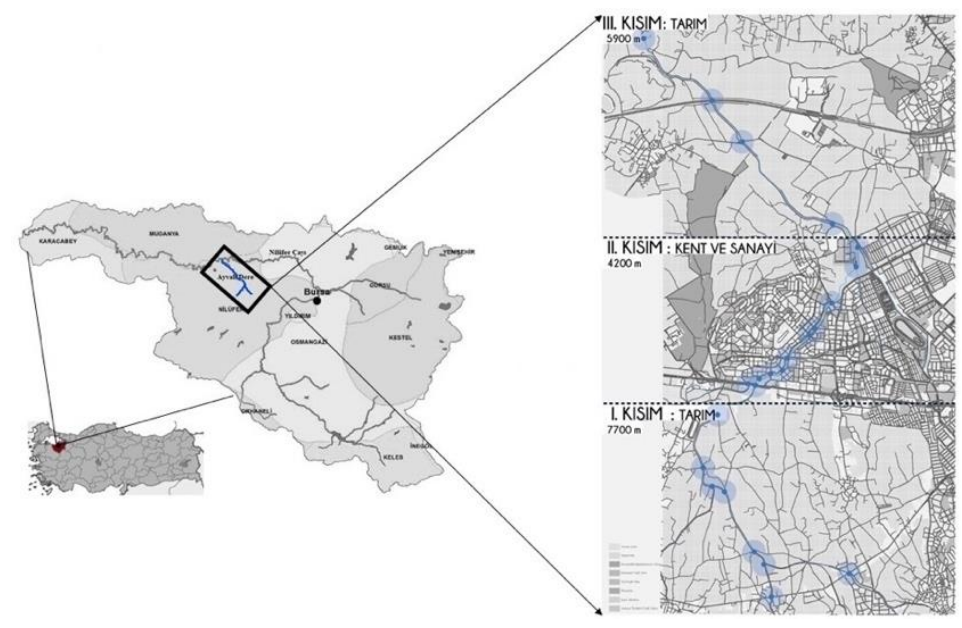

Şekil 1. Ayvalı Dere Çalışma Alanı ve Ses Ölçüm Noktaları, Nilüfer Bursa

\section{Bulgular ve Tartışma}

Bugular bölümü dünya örnekleri ve ses ölçümlerine ilişkin bulgu ve tartışmalar şeklinde verilmiştir.

\subsection{Dünya Örnekleri}

Dünya örnekleri, sekiz farklı örneği içermektedir.

\subsubsection{Paley Parkı}

New York'un en işlek merkezinden biri olan Manhattan'da yer alan Paley Parkı yüksek binalarla çevrilmiştir. Yoğun kentleşme nedeniyle yoğun bir şehir gürültüsü altında olan bu park, özellikle öğle ve akşam saatlerinde çevresindeki iş ve ticaret merkezleri kullanıcıları tarafından ziyaret edilmektedir. Dolayısı ile bu parkın bitişiğinden geçen yolda yoğun araç trafiği söz konusu olmaktadır. Bu nedenle insan ve trafik kaynaklı gürültü kirliliğini önlemek amaciyla parkta trafiğin ve sirkülasyonun akış yönünün tam tersi yönünde duvardan akan bir şelale tasarlanmıştır (Şekil 2). Böylece kentin yoğun yapılaşma baskısı altında olan ve minik bir vaha etkisi gösteren bu parkta, şelale etkisi ile oluşturulan su sesi sayesinde gürültü kirliliği maskelenmiştir (Armato, 2017; Labuz, 2019).
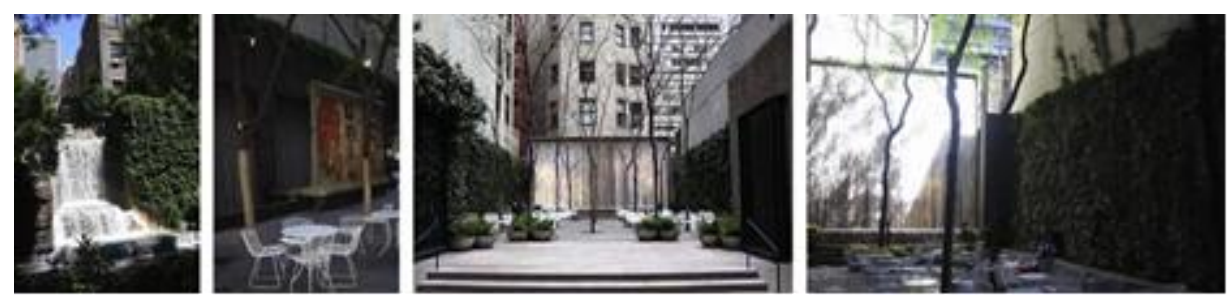

Şekil 2. Paley parkı ve şelale tasarımı (Soundscapedesign, 2021)

\subsubsection{Sheaf Meydan1}

İngiltere'nin Sheffield kentinde bulunan Sheaf Meydanında, işitsel peyzaja yönelik geliştirilen tasarım elemanları trafik gürültüsünü filtrelemeyi amaçlamaktadır. Özellikle yoğun araç kullanımına sahip yolun bitişiğinde yer alan meydanda, alınan ses ölçümleri sonucunda şiddetli bir gürültü kirliliğinin olduğu tespit edilmiştir. Bu kapsamda yol kenarında özellikle trafiğin sesinin yüksek olduğu kesimlerde tasarlanan çelik bariyerlerin ve meydanın içerisinde kullanılan hareketli su öğesinin trafik kaynaklı oluşan bu gürültü kirliliğini azalttığı belirlenmiştir (Şekil 3) (Xiao vd., 2017; Cerwén, 2018; Oberman vd., 2019). 

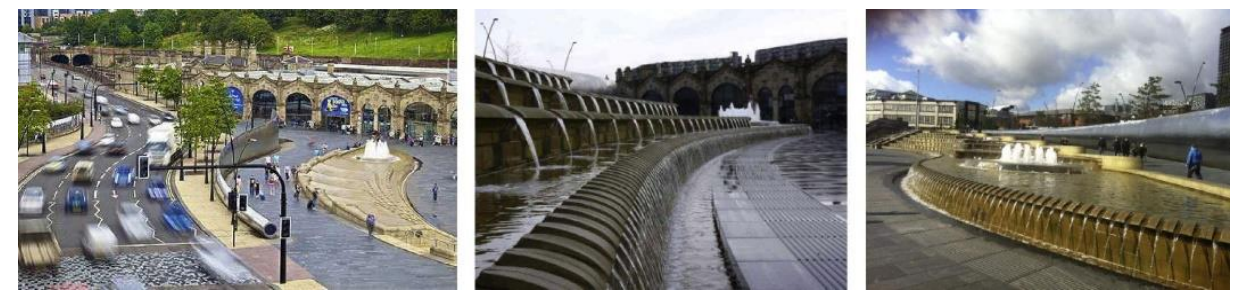

Şekil 3. Sheaf Meydanı ses bariyeri ve su kullanımı (Urbanidentity, 2021)

\subsubsection{Buitenschot Park}

Kuzey Hollanda'nın Haarlemmermeer belediyesinde bulunan ve havalimanı pistine oldukça yakın olan Buitenschot Parkı tasarlanırken iniş ve kalkışlarda oluşan uçak gürültüsünün azaltılması hedeflenmiştir. Bu kapsamda getirilen tasarım çözümü için 3 metre uzunluğunda setler önerilmiştir. Gürültü yapan ses dalgalarına dik olan setler, gelen sesi filtrelemek ve aynı zamanda kullanıcılar için rekreasyonel olanak ve estetik bir etki sağlamıştır (Şekil 4). Parkı rekreasyonel ihtiyaçlarını karşılamak amacı ile gelen ziyaretçilerin uçak seslerinden gelen sesleri büyük oranda azalmasını sağlamak amacı ile organik bir örtü ile kaplanarak dik yerleştirilmiş olan bu setler, parka ilginç bir estetik doku da kazandırmıştır (Architects, 2016; Berkers, 2016; Girot; 2016; A ğaçsapan \& Çabuk, 2019; WLA, 2021)

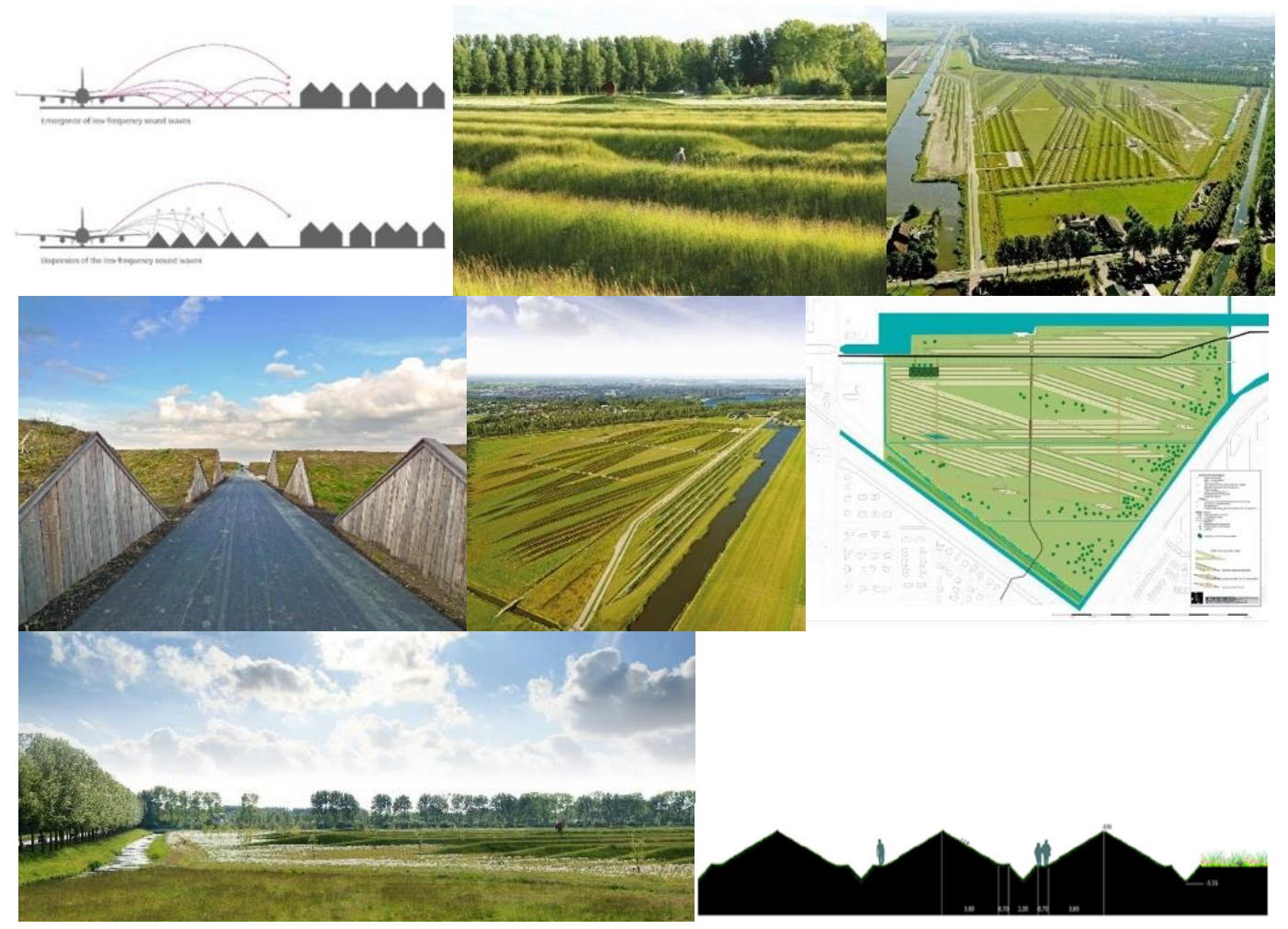

Şekil 4. Buitenschot Park1 ses bariyeri (Girot, 2016; Landezine, 2016; WLA, 2021)

\subsubsection{Deniz Orgu}

Hırvatistan'ın Zadar kentinin, İkinci Dünya Savaşı'nda uğradığı yıkımı onarmak amacıyla ve kentliyi savaşın etkilerinden uzaklaştırarak su sesine vurgu sağlamak amacı ile kentin kıyısında Deniz Orgu isimli bir park tasarlanmıştır. Bu parkta akustik konfor sağlayan temel işitsel peyzaj elemanı olarak suyun etkisi kullanılmış ve bu amaçla, terapi niteliğinde olan deniz dalgaları parkın tasarım sürecine entegre bir şekilde kullanılmıştır. Denize inen basamaklarla deniz ve insan ilişkisini arttırılmıştır. Basamaklar altında kullanılan 35 adet boru adeta bir müzik aleti görevi görmektedir. Deniz gelgitleri sayesinde park sürekli olarak işitsel peyzaj konseptine hizmet vermektedir (Claus \& Park, 2018; Denić-Jukić, 2019; Oberman vd., 2020). Bu park rekreasyonel anlamda yarattığı bu etki nedeniyle 2005-2006 yılında Kentsel Kamusal Alan için Avrupa Ödülünü almaya hak kazanmıştır (Şekil 5). 


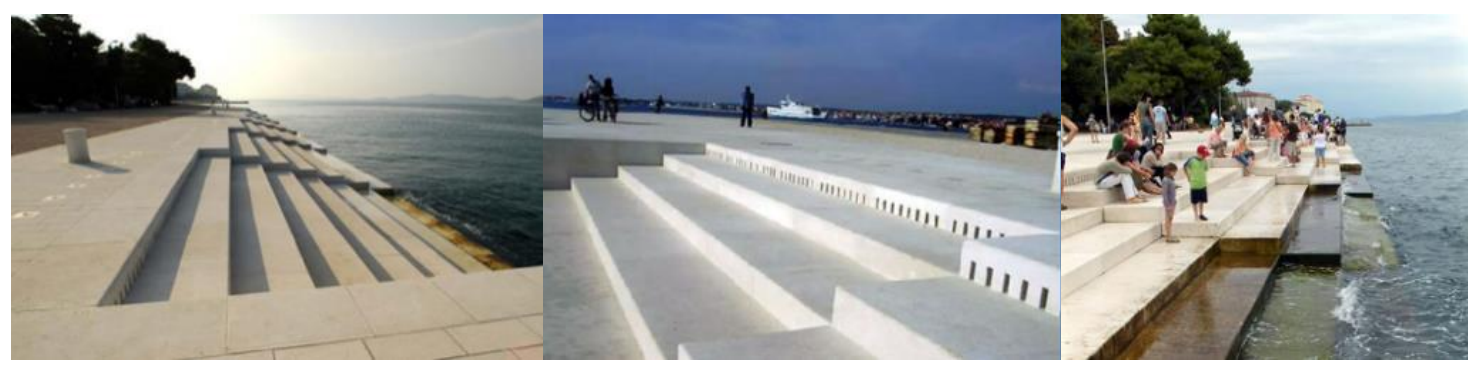

Şekil 5. Deniz orgu tasarımı (Oddmusic, 2021)

\subsubsection{Eneborgsplatsen Park}

İsveç'in Helsingborg kent merkezinde bulunan park, akustik konfor sağlamak üzere işitsel peyzaj konseptinde revize edilmiştir. Ses duvarı yapılmadan önce parkta ses ölçümünün $60 \mathrm{~dB}(\mathrm{~A})$ olduğu ölçülmüştür. Oysaki İsveç Çevre Koruma Ajansı'na göre kamusal alan olan parklarda ses ölçümünün en fazla $55 \mathrm{~dB}(\mathrm{~A})$ olması gerektiği belirlenmiştir. Bu amaçla, trafik sesinin yoğun olduğu alanda sesi önlemek için tuğla örülü bitki duvarları düşünülmüştür. Ancak bu duvarların park için sürdürülebilir olmadığ1 düşünüldüğü için yüksek ses perdeleri yerine daha kısa 1 metrelik tığla bariyerler kullanılmıştır (Şekil 6). Bu bariyerler sesi emmek için özel tasarlanmıştır. Duvara yakın olan mesafelerde ses duvarının daha etkili olduğu belirlenmiştir. Buna göre bariyere yakın olan bölgelerde gürültü $12 \mathrm{~dB}(\mathrm{~A})$ kadar azalırken, 12 metre mesafede bulunan konut bölgesinde ise gürültünün $7 \mathrm{~dB}(\mathrm{~A})$ azaldığı, parka yakın olan bölgede 6 $\mathrm{dB}(\mathrm{A})$, yoldan mesafe arttıkça parkın ortasında ise trafikten kaynaklanan gürültünün $4 \mathrm{~dB}(\mathrm{~A})$ azaldığ 1 tespit edilmiştir (Osvalder \& Nybacka, 2018; Cerwén \& Mossberg,2019; Emilson vd., 2020).

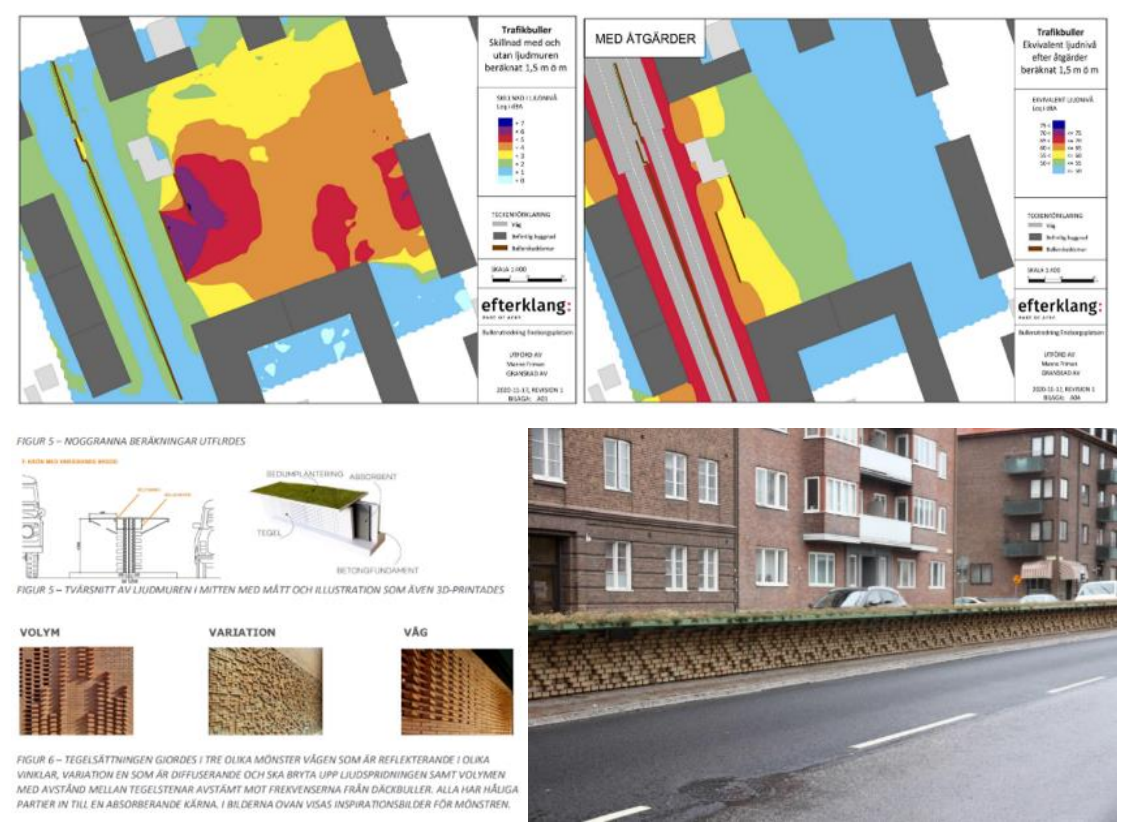

Şekil 6. Tuğla örülü ses duvarları (Emilson vd., 2020; Omvarldsbevakning, 2020)

\subsubsection{Nauener Meydanı}

Berlin'deki Nauener meydanında trafik ve insan yoğunluğundan dolayı oluşan gürültü kirliliğinin oldukça fazla olduğu belirlenmiştir. Bu nedenle meydan akustiği konusunda uzman Prof. Dr. Brigitte Schulte-Fortkamp ve Berlin Teknik Üniversitesindeki ilgili uzmanlar tarafından tekrar revize edilmek üzere tasarlanmıştır. Revize edilmeden önce ses ölçümleri alınarak gürültünün olduğu hatlar belirlenmiştir. Bu kapsamda gürültü haritaları çıkarmak amacıyla meydan kullanıcıları tarafından ses yürüyüşleri gerçekleştirilmiştir. Gürültünün yoğunlaştığı alanlar tespit edilmiş ve bu alanlara çeşitli akustik öneriler getirilerek akustik konfor oluşturulması sağlanmıştır. Elde edilen sonuçlara göre parkta sesli oturma elemanlarından akustik konforu sağlayan ses adaları oluşturulmuştur. Bu banklar sayesinde kullanıcılar gün içerisinde dalga sesi, kuş sesi gibi birçok huzur veren doğal ses unsurlarını duymaktadır (Şekil 7). Aynı zamanda alanda gürültü duvarları oluşturulmuştur. Bu duvarlar sayesinde ses 
ölçümlerinde $3 \mathrm{~dB}(\mathrm{~A})^{\prime}$ lik bir azalma gözlemlenmiştir (Schulte-Fortkamp \& Brooks, 2018; Mancini vd., 2021; Radicchi vd., 2021). Oturma elemanlarından yayılan ses ve trafik gürültüsü beklenmeyen farklı bir uyum sağlayarak garip bir harmoni oluşturmuştur (Schulte-Fortkamp \& Brooks, 2018). Proje nedeniyle Prof. Dr. Schulte-Fortkamp'a Kasım 2012'de Avrupa Ses Manzarası Ödülü verilmiştir.


Şekil 7. Gürültü bariyeri ve ses bankları (Schlüter, 2013; Schulte-Fortkamp \& Brooks, 2018)

\subsubsection{Gürültü Tüneli}

Çin'in Shenzhen ilinde bulunan bu bariyer, trafik yoğunluğu olan otoyolda gürültünün en yoğun olduğu bölgeye tünel formunda güneş ısınlarını içerisine geçirebilen yarı-kapalı bir yapı tasarlanmıştır. İnşaat maliyetini en aza indirmek için geri dönüştürülmüş malzemeler olan plastik şişe, PV, cam çatı pencereleri, katı panelleri ve bitkisel örtüsünden ve hafif çelikten oluşturulan bu tünel, gürültünün rahatsız edici etkisini azaltmaktadır (Şekil 8). Yapıdaki PV dolgusu bariyer ve çevresindeki otoyol aydınlatması için elektrik üretmekte ve depolanmaktadır, bariyerdeki bitki örtüsü dolgusu otoyoldan gelen 1s1 radyasyonunu azaltmaktadır. Boşluklu yapısı sayesinde sesi toplaması ve izole etmesi ile otoyoldan gelen gürültünün azaldığı tespit edilmiştir. Böylece çevreye duyarlı bir şekilde tasarlanmış olan bu gürültü bariyeri hem otoyol kullanıcıları hem de çevre mahallerdeki kullanıcıları için otoyol gürültüsünü izole etmektedir (Han vd., 2018; Bao \& Lu, 2021).



Şekil 8. Gürültü bariyeri tasarımı (Archello, 2021).

\subsubsection{Meydan Park, Fatih Park ve Atapark}

Trabzon merkezde yol bitişiğinde olan Meydan Park, Fatih Park ve Atapark için yürütülen bu çalışma kapsamında gürültüyü filtre edilmesi amacı ile kullanılan bitki örtüsünün 2007-2014 yıllarında iki farklı dönemde sesi azaltma etkisi incelenmiştir. Bu kapsamda alınan ses ölçümlerine göre kullanılan farklı bitki türleri, bitkilerin büyüme hızlarındaki farklılık ve parkların kullanım biçimlerinin farklı olması (çocuk oyun alanı, çay bahçesi, oturma birimleri) nedeni ile Meydan parkında gürültü seviyesinin $14.24 \mathrm{~dB}(\mathrm{~A})$, Fatih Parkında $6.16 \mathrm{~dB}(\mathrm{~A})$ ve Atapark'da ise $9 \mathrm{~dB}(\mathrm{~A})$ azalttığ 1 tespit edilmiştir. Sonuç olarak, gürültü seviyesi ve koşulları benzerlik gösteren bu çalışmalarda yolu perdeleme amaçlı kullanılan bitkilerin büyümesi ve kapalılığının artması ile birlikte gürültü kirliliğini bir önceki döneme göre azaldığı tespit edilmiştir. Ancak bu gürültü seviyesi bu yıllar içinde azalsa bile ÇGDYY Yönetmeliği gereği üst sınır olan $60 \mathrm{~dB}(\mathrm{~A})$ değerinin üzerinde olduğu belirlenmiştir (Özdemir vd., 2014).

\subsection{Ses Ölçümleri Bulguları ve Tartışma}

İşitsel peyzaj temelli tüm bu örnek çalışmalara bakıldığında, doğal ve/veya yapay tasarım öğeleri kullanılarak çalışmanın bulunduğu alana akustik konfor oluşturulmaktadır. Bu tasarım öğeleri gürültü ölçümlerinin yüksek olduğu alanlar dikkate alınarak yerleştirilmekte ve böylece yakın çevrede yaşayanlar ve diğer kullanıcılar için gürültünün rahatsız edici etkisinin absorbe edilmesi hedeflenmektedir. Bu dünya 
Eşbah H. O., Demir, S., \& Yıldırım Y. (2022). Akarsu Koridorlarında Akustik Konforun Değerlendirilmesinde İşitsel Peyzajın

Rolü, Ayvalı Dere Örneği. GSI Journals Serie A: Advancements in Tourism, Recreation and Sports Sciences (ATRSS), 5 (1): 27-43

örneklerinde incelendiğinde fiziksel, fizyolojik ve psikolojik olarak insan sağlığı üzerinde oldukça etkili olan gürültünün özellikle ulaşım kaynaklı araç trafiği ve insan yoğunluğundan kaynaklandığı tespit edilmiştir (Tablo 1).

Tablo 1. Dünyadaki işitsel peyzaj örnekleri, özellikleri ve akustik konfor sağlayan doğal ve yapay tasarım kriterleri

\begin{tabular}{|c|c|c|c|c|}
\hline Parkın Adı & Özellikler & Problem & Çözüm & Kriterler \\
\hline Paley Parkı & $\begin{array}{l}\text {-New York } \\
\text {-Kent merkezi }\end{array}$ & $\begin{array}{l}\text {-Şehir gürültüsü } \\
\text {-İnsan } \\
\text { yoğunluğu } \\
\text {-Trafik sesi }\end{array}$ & $-\mathrm{Su}$ & $\begin{array}{l}\text {-Trafik ve insan yoğunluğunu örtmek } \\
\text { duvar şeklinde şelale kullanılmıştır. }\end{array}$ \\
\hline Sheaf Meydanı & $\begin{array}{l}\text {-Sheffield } \\
\text {-Kent merkezi }\end{array}$ & -Trafik sesi & -Su Duvar & $\begin{array}{l}\text {-Yoğun trafik geçen alanda gürültü } \\
\text { kirliliğini bastırmak için su ögesi ve çelik } \\
\text { duvar kullanılmıştır. }\end{array}$ \\
\hline Buitenschot Parkı & $\begin{array}{l}\text {-Haarlemmermeer, } \\
\text { Hoofddorp } \\
\text {-Havalimanı }\end{array}$ & -Uçak sesi & -Duvar & $\begin{array}{l}\text {-Park içerisinde } 3 \mathrm{~m}^{\prime} \text { lik setler oluşturularak } \\
\text { uçak seslerinin azaltılması, rekreatif ve } \\
\text { estetik alanlar oluşturulması } \\
\text { amaçlanmıştır. }\end{array}$ \\
\hline Deniz Orgu & $\begin{array}{l}\text {-Hirvatistan } \\
\text {-Kent merkezi } \\
\text {-Deniz kıyısı } \\
\end{array}$ & $\begin{array}{l}\text {-Şehir gürültüsü } \\
\text {-İnsan } \\
\text { yoğunluğu }\end{array}$ & $-\mathrm{Su}$ & $\begin{array}{l}\text {-Deniz kıyısında bulunan bu park denizin } \\
\text { gelgitlerini kullanarak bir müzik aleti } \\
\text { oluşturmuştur. }\end{array}$ \\
\hline $\begin{array}{l}\text { Eneborgsplatse } \\
\text { Park1 }\end{array}$ & $\begin{array}{l}\text {-İsveç } \\
\text {-Kent merkezi }\end{array}$ & -Trafik sesi & -Duvar & $\begin{array}{l}\text {-Daha önceden yapılan parkta trafik sesini } \\
\text { azaltmak için uzun bitki duvarları yerine } \\
\text { daha kısa ve aralıklı duvarlar tercih } \\
\text { edilmiştir. }\end{array}$ \\
\hline Nauener Meydanı & $\begin{array}{l}\text {-Berlin } \\
\text {-Kent merkezinde }\end{array}$ & $\begin{array}{l}\text {-Trafik sesi } \\
\text {-İnsan } \\
\text { yoğunluğu }\end{array}$ & $\begin{array}{l}\text {-Oturma } \\
\text { elemanları } \\
\text {-Duvar }\end{array}$ & $\begin{array}{l}\text {-Oturma elemanları sayesinde trafik } \\
\text { gürültüsü bastırılarak kullanıcı dostu bir } \\
\text { meydan oluşturulmuştur. }\end{array}$ \\
\hline Gürültü Bariyeri & $\begin{array}{l}\text {-Çin } \\
\text {-Kent merkezinde }\end{array}$ & -Trafik sesi & -Bariyer & $\begin{array}{l}\text { - Geri dönüştürülmüş malzemeden } \\
\text { oluşturulan bariyerler formu ve malzemesi } \\
\text { nedeniyle sesi absorbe etmektedir. }\end{array}$ \\
\hline $\begin{array}{ll}\text { Meydan } & \text { Park1, } \\
\text { Fatih } & \text { Park1, } \\
\text { Atapark } & \end{array}$ & $\begin{array}{l}\text {-Trabzon } \\
\text {-Kent merkezinde }\end{array}$ & $\begin{array}{l}\text {-Trafik sesi } \\
\text {-İnsan } \\
\text { yoğunluğu }\end{array}$ & -Bitki & $\begin{array}{l}\text {-Yapılan bir çalışmada bu parklarda, } \\
\text { belirlenen bitkiler ile oluşturulan bitki } \\
\text { duvarları sayesinde, gürültü kirliliklerinde } \\
\text { azalma olmuştur. }\end{array}$ \\
\hline
\end{tabular}

Dünya örneklerine bakıldığında gürültü problemine yönelik farklı ülkelerde işitsel peyzaja yönelik geliştirilen doğal ve/veya yapay tasarım çözümleri şunlardır;

1. Kentte trafik ve insan yoğunluğundan kaynaklı gürültüyü filtreleme amacı ile getirilen doğal çözümler bitki ve su odaklı olarak geliştirilmektedir.

2. Gürültüyü absorbe etmek amacı ile getirilen yapay tasarım çözümleri ses duvarı ve kentsel donatılar olarak ele alınmaktadır.

3. Hem doğal hem yapay tasarım çözümleri bir arada değerlendirilmekte ve bu kapsamda bitkili gürültü bariyeri, su duvarı, doğa sesi ile çalışan müzik aleti kullanılmaktadır.

4. Akustik konforun sağlanması amacı ile çalışma alanına kentin stresinden ve gürültüsünden uzaklaştıran kuş, su, yaprak sesi gibi doğal ve huzur verici sesler kullanılmaktadır.

Dünya örnekleri dikkate alındığında çalışma alanında üç farklı bölgede ses ölçümleri alınmıştır (Şekil 9). Ölçümler dere kollarının birleşim noktaları, yolun dereyi kestiği noktalar, dere üzerinden geçen köprüler, trafik 1şıklarının olduğu noktalar, dört yol ağılarından ve sportif aktivitelerin ve rekreasyonel aktivitelerin gerçekleştiği alanlardan alınmıştır. Derenin ilk aktığı bölgede tarımsal odaklı kırsal alanda 8, derenin aktığ ikinci bölge olan yerleşim ve sanayi bölgesinde 11, derenin Nilüfer çayına döküldüğü tarım odaklı son bölgede 4 noktadan olmak üzere KGM (2020)'e göre trafiğin yoğun olduğu hafta içi sabah 08.0010.00 ile akşam 17-00-19.00 saatleri arasında toplam 23 noktanın her birinden üçer dakikalık ölçümler 
alınmıştır. Bu zaman aralıklarının dışında her noktadan ayrı ayrı alınan ses ölçümleri $50 \mathrm{~dB}(\mathrm{~A})$ değerinin altında çıkmıştır. Yapılan gürültü kaynakları sınır düzeyleri hesaplamaları ÇGDY Yönetmeliğine göre hesaplanmış ancak zaman aralıkları KGM (2020)' ye göre belirlenmiştir. İlk bölgede 8 noktadan ayrı ayrı alınan ses ölçümlerinin ortalaması $63.6 \mathrm{~dB}(\mathrm{~A})$, derenin geçtiği ara bölgede 11 noktadan alınan ses ölçümlerinin ortalaması $69.6 \mathrm{~dB}(\mathrm{~A})$, son bölgede 4 noktadan alınan ses ölçümlerinin ortalaması $61.3 \mathrm{~dB}(\mathrm{~A})$ olarak alınmıştır (Tablo 2). Sonuçlar dikkate alındığında, Ayvalı Dere kırsal, kentsel, sanayi gibi farklı dokulardan geçmesine rağmen koridoru boyunca alınan ses ölçümleri değerlerinin ÇGDY Yönetmeliği gereği üst sınır olan $60 \mathrm{~dB}(\mathrm{~A})$ değerinin üzerinde olduğu tespit edilmiştir. ABD'de Konut ve Şehir Geliştirme Bölümü tarafından ise dış mekanlarda $62 \mathrm{~dB}(\mathrm{~A})$ değerin altındaki ses ölçümleri kabul edilebilir bir değerken bu değerin üstündeki ses ölçümleri kabul edilemez bir ses düzeyini ifade eder (Demirkale \& Aşçıgil, 2007; Bayramoğlu ve diğerleri, 2014; Oberman vd., 2020; Radicchi vd., 2021). Ayrıca derenin aktığ1 ikinci bölge olan yerleşim ve sanayi bölgesinden geçen dere boyunca ortalama $69.6 \mathrm{~dB}(\mathrm{~A})$ ses değeri ölçülmüştür.

Özellikle İzmir yolun kestiği kırsal bir tarım alanı olan birinci bölgenin 8. noktasından alınan ses ölçümünün (67dBA) aynı bölgede alınan diğer yedi noktadan daha yüksek çıkması İzmir yolunun yoğun trafik akışından kaynaklanmaktadır. Bu değer, ÇGDY Yönetmeliği gereği kırsal alanlardan geçen karayolu çevresi gürültü üst sınır değeri olan üst sınır olan $60 \mathrm{~dB}(\mathrm{~A})$ değerinin üzerindedir. Benzer şekilde yoğun yapılaşmanın başladığı ikinci bölgenin 1. ve 2. noktalarından alınan ses ölçümlerinin (82-84 dBA) yüksek olması da İzmir yolunun dereyi kesmesinden kaynaklanmaktadır. Bu değerler, ÇGDY Yönetmeliği gereği A (<55 dBA), B (55-64 dBA), C (64-74 dBA) yerleşim kategorileri giren bölgelerdeki gürültü üst sınırını aşmaktadır. Sanayinin sona erdiği ve tarımın başladığı üçüncü bölgenin 1. noktasından alınan ses ölçümlerinin diğer üç noktadan daha yüksek çıkması Nilüfer Organize Sanayi Bölgesinin çıkısında bulunması ve yoğun trafik akışının olmasından kaynaklanmaktadır. Bu değerin de ÇGDY Yönetmeliği gereği kırsal alanlardan geçen karayolu çevresi gürültü üst sınır değeri olan $60 \mathrm{~dB}(\mathrm{~A})$ değerinin üzerinde olduğu analiz edilmiştir. Bayramoğlu vd., (2014), Özdemir vd., (2014), Han vd., (2018) ve Radicchi vd., (2021)'e göre ÇGDY Yönetmeliği gereği 65 dB(A) üzerinde çıkan ses ölçümü, konforsuzluk, rahatsızlık, kızgınlık, konsantrasyon ve uyku bozukluğu gibi fizyolojik ve psikolojik açıdan sağlık sorunları oluşturabilmektedir.

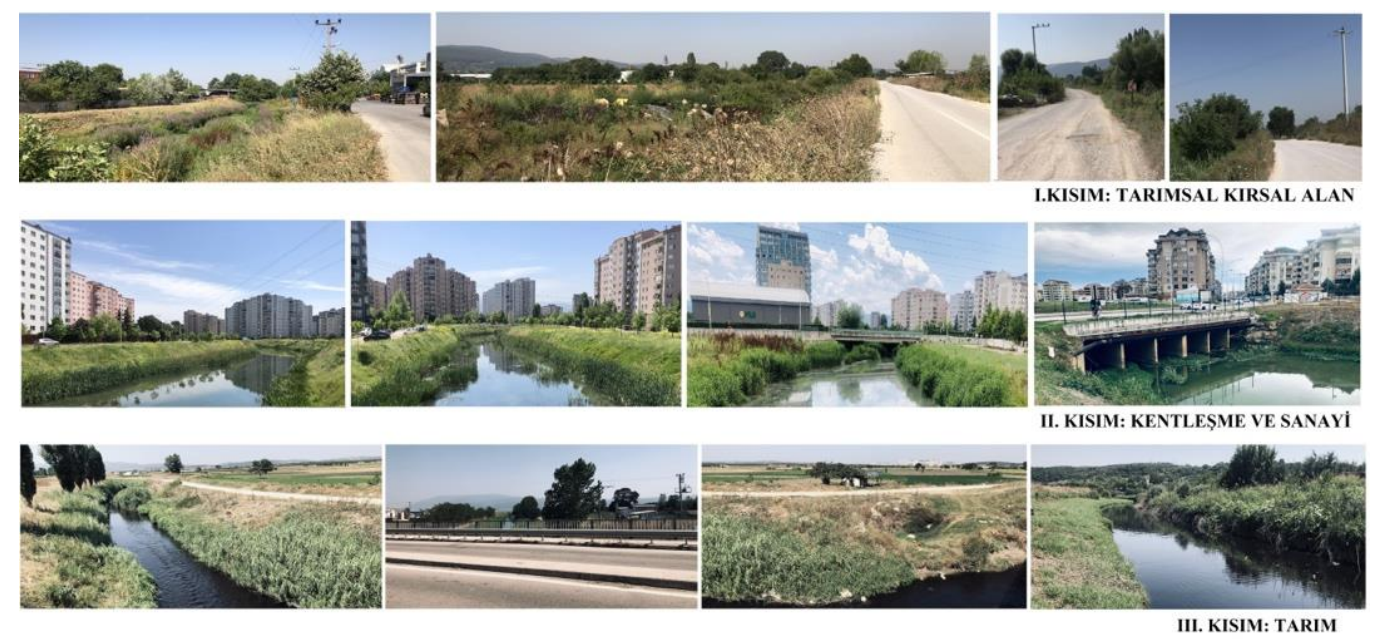

Şekil 9. Çalışma alanının üç farklı bölgesinden görüntüler

ABD Çevre Koruma Kurumu tarafından dış mekanlarda 55 dB(A) üstündeki ses değerinin aktiviteleri engellediği ve baş ağrısına sebep olduğunu bildirmiştir. Benzer şekilde ABD'de Konut ve Şehir Geliştirme Bölümü kuralları gereği dış mekanlarda ve yerleşim alanı içerisinde $65 \mathrm{~dB}(\mathrm{~A})$ değerlerinin en üst gürültü seviyesi olduğunu binalara yakın yerlerde ise bu seviyenin en fazla $45 \mathrm{~dB}(\mathrm{~A})$ olması gerektiğini belirtmişlerdir (Demirkale \& Aşçıgil, 2007; Bayramoğlu vd., 2014; Özdemir vd., 2014; Oberman vd., 2019; Oberman vd., 2020). Ayvalı Dere koridoru boyunca araç yolu ve özellikle Ayvalı Dereyi dik kesen İzmir otoyolu nedeni ile akustik konforu olumsuz yönde etkileyen trafik kaynaklı bir gürültü yaşanmaktadır. Türkiye'nin ÇGDY Yönetmeliği gereği kara yolu çevresinde gürültü sınır değerleri belirlenmiştir. Buna 
Eşbah H. O., Demir, S., \& Yıldırım Y. (2022). Akarsu Koridorlarında Akustik Konforun Değerlendirilmesinde İşitsel Peyzajın

Rolü, Ayvalı Dere Örneği. GSI Journals Serie A: Advancements in Tourism, Recreation and Sports Sciences (ATRSS), 5 (1): 27-43

göre çalışma alanı olan Ayvalı Dere paralelinde uzanan kara yolu boyunca kırsal alanda $63.6 \mathrm{~dB}(\mathrm{~A})$ olarak ölçülen değerin yönetmelik gereği $55 \mathrm{~dB}(\mathrm{~A})$, yerleşim alanında $63 \mathrm{~dB}(\mathrm{~A})$ ve endüstriyel alanda $67 \mathrm{~dB}(\mathrm{~A})$ olması gereken değerin ise $69.6 \mathrm{~dB}(\mathrm{~A})$ olarak ölçülmesi ve son olarak $55 \mathrm{~dB}(\mathrm{~A})$ üst sınırında olması gereken ses ölçüm değerinin tarım alanlarının yoğun olduğu yol boyunca ortalama $61.3 \mathrm{~dB}(\mathrm{~A})$ olması nedeni ile kara yolu çevresinde olması gereken üst sınırın aşıldığı analiz edilmiştir.

Çalışmada gürültü ölçüm aracı olarak OKTAVA 110A-PRO ile kalibre edilmiş olan "dB meter lite" adlı ses ölçümü yapan telefon uygulaması kullanılmıştır. ÇGDY Yönetmeliği kapsamında ses ölçümleri aletleri ve bunlarda olması gereken kalibrasyon değeri tanımlanmamıştır. Ancak bu eksikliğe rağmen sonraki çalışmalarda bir telefon uygulamasına göre daha yüksek kalibrasyon değerine sahip ses ölçüm cihazlarının kullanılması ve yönetmelikte belirlenen gündüz-akşam-gece saatlerinde ölçümlerin alınması araştırmanın hassasiyetini arttırması ve dolayısı ile kesin sonuçlar vermesi açısından oldukça önemlidir.

Tablo 2. Çalışma alanı ortalama ses ölçümleri dB(A)

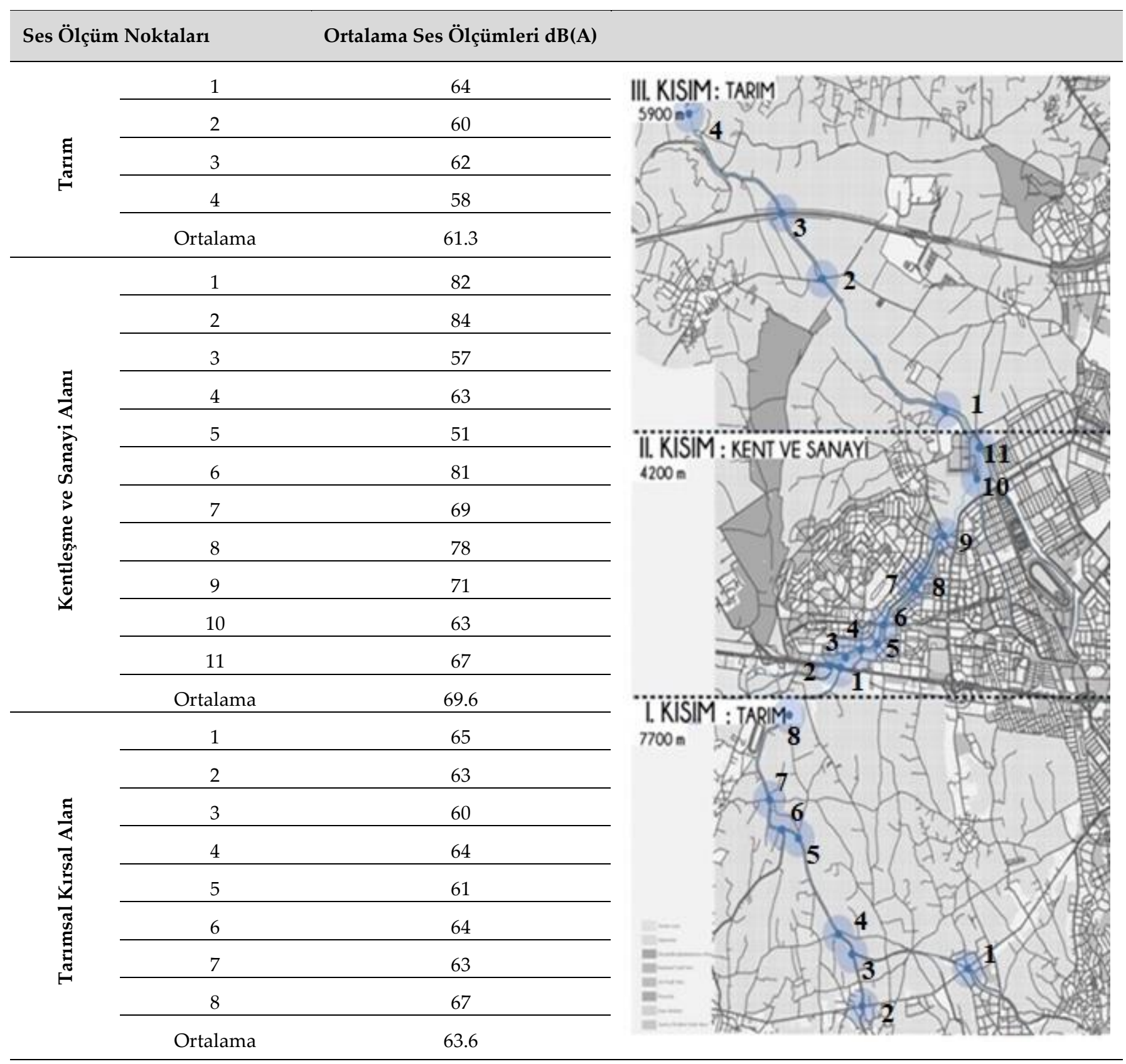

\section{4. Öneriler}

Ayvalı Dere boyunca uzanan çalışmada doğa ile ilişkili sesleri korumak, ön plana çıkarmak, farkındalığını sağlamak ve çoğaltmak için akustik konforun değerlendirilmesi hedeflenmiştir. Rekreasyon alanlarında 
su, kuş ve yaprak sesi ile ziyaretçi sesi ve bunlar arasındaki fiziksel, fizyolojik ve sosyolojik etkileşim, çalışma alanı ve çevresinin işitsel olarak algılanan akustik çevresini oluşturmaktadır. Bu sebeple araştırma alanında akustik konforun sağlanması için bu seslerin geliştirilmesi üzerinde çalışılmıştır. Dolayısıyla rahatlatıcı etkisi ile suyun akış yönüne göre su sesi ve yaprak sesi arttırılması ve su odaklı olan rekreasyon alanlarında yapılan bitkisel tasarım çalışmaları ile kuşların bu alanlara çekilmesi sağlanarak kuş sesinin artırılması işitsel peyzaj kavramı kapsamında önerilmiştir. Bu bağlamda çalışma alanında gürültü kaynakları tespit edilmiş ve gürültü seviyesini düşürmek için çözüm önerileri geliştirilmiştir. Sonuç olarak dünya örneklerindeki işitsel peyzaja yönelik geliştirilen çözüm önerilerinden yola çıkılarak akustik konforun değerlendirilmesi kapsamında alandaki bu sesleri korumak, ön plana çıkarmak, farkındalığını sağlamak ve çoğaltmakla birlikte gürültü seviyesini azaltmak için su, ses duvarı ve bariyeri, bitkisel materyal, kentsel donatı gibi doğal ve yapay peyzaj elemanlarını bir arada değerlendiren aşağıdaki tasarım çözümleri geliştirilmiştir.

Su kapsamında getirilen öneriler ile dere içerisinde ve suyun akış yönüne doğru Hırvatistan'daki Deniz Orgu Parkı örneğindeki gibi köprü ayaklarına yapılacak olan su ile etkileşim içinde olan boruların konulması ve ayrıca dere ile yolun dik olarak kesiştiği üst yollarda gürültüyü azaltmak amacı ile su duvarlarının tasarlanması hedeflenmektedir (Şekil 9).
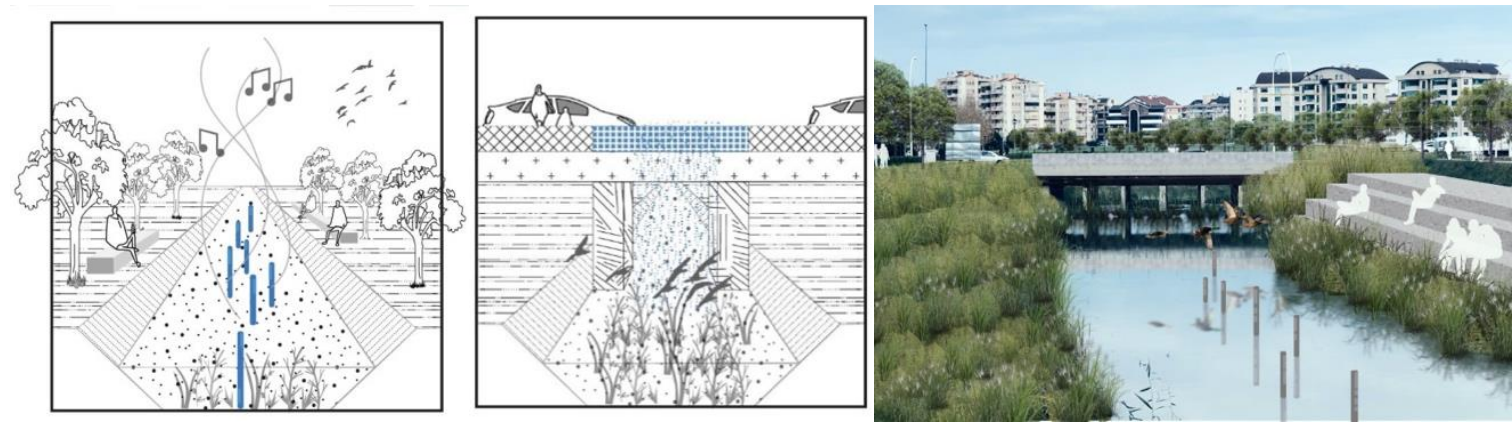

Şekil 9. Dere içerisinde müzik aletleri

Dereyi kesen araca yönelik köprülerin kenarlarına yapılacak olan ses duvarları, gürültü kirliliğini dünya örneklerinde olduğu gibi büyük ölçüde azaltması beklenmektedir. Yapılan ses ölçümleri sırasında araçların durma-kalkma alanları olan trafik ışıklarının olduğu alanlarda ses duvarları önerilmektedir (Şekil 10).
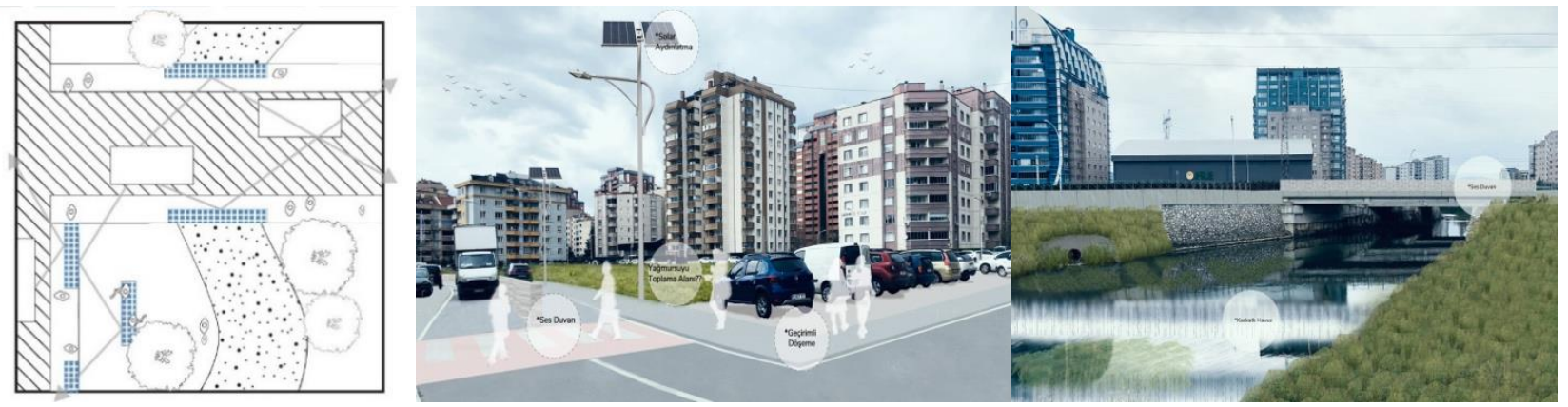

Şekil 10. Ses duvarı

Gürültü kirliliğinin yoğun olarak tespit edildiği bölgelerde, çalışma alanına özgü bitki materyallerinin kullanıldığı bitki duvarlarının tasarlanması gürültüyü dünya örneklerindeki gibi 3-5 dB azaltması amaçlanmaktadır. Ayrıca yapılacak bitkilendirme ile alanda yaprak seslerinin ve kuş sesleri gibi doğal seslerin alana getirilmesi hedeflenmektedir.

Dere kenarındaki rekreasyonel alanlarının yakınından geçen yolda araç trafiğinin yol açtığı gürültüyü ses duvarı, ses bariyeri ve su öğesi ile azaltmanın yanı sıra gürültüyü perdeleyen ve aynı zamanda sahip olduğu ses sistemi ile kuş sesleri ve doğa sesleri çalan oturma birimleri gibi kentsel donatı elemanlarının kullanılması önerilmekte ve kullanıcılara akustik konfor sağlaması amaçlanmaktadır (Şekil 11). 


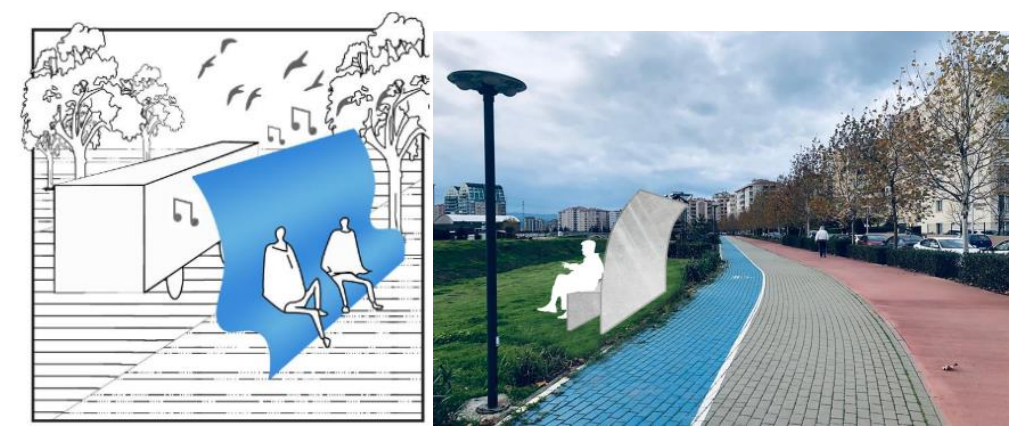

Şekil 11. Ses sistemi olan kentsel donatı elamanı

Çalışma alanını dik kesen ve trafik yoğunluğu fazla olan İzmir Yolu otobanı ve dereye paralel uzanan kimi yerlerde dereyi dik kesen karayolları bulunmaktadır. Bu yollar üzerinde ses ölçümleri yüksek olan bölgelerinde kullanılacak ses bariyerlerinin rekreasyonu olumsuz etkileyecek su kenarı çevresindeki ve konut çevresindeki gürültü kirliliğini azaltması hedeflenmektedir (Şekil 12).
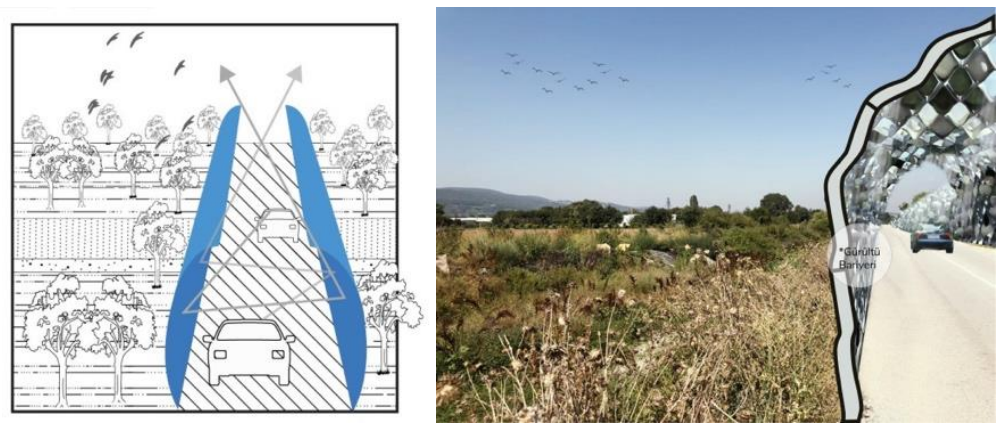

Şekil 12. Bariyer

\section{Sonuç}

Avrupa Peyzaj Sözleşmesine göre insanlar tarafından algılandığı şekliyle, karakteri doğal ve/veya insani unsurların eyleminin ve etkileşimi sonucu oluşan bir alan anlamına gelen peyzajın tanımında yer alan; insan tarafından algılanış biçiminden biri aslında işitme eylemidir. Dolayısı ile gürültüden kaynaklı olan rahatsız edici seslerin, insanların direkt etkileşim içerisinde bulundukları kent dokusu içerisindeki yerlerinin dikkate alınması ve işitsel peyzaj kapsamında akustik konforun sağlanabilmesi konusunda da değerlendirilmesi gerekmektedir.

Kentlerdeki derelerin taşkın alanlarının kamulaştırılıp kotlarının düşürülmesi suyun daha geniş alanlara akmasına ve dolayısı ile hızının azalmasına olanak sunmaktadır. Bu kapsamda taşkın alanlarının, parklar, spor alanları, yürüyüş ve bisiklet yolları gibi çevresinde bulunan yeşil koridorları ile birlikte tasarlaması, kentin yaşam kalitesini arttırmaktadır. Bu kamulaştırılan alanlar kentin gürültülü ve stresli ortamından kentlileri uzaklaştırarak doğa sesleri ile oluşan akustik konfor içerisinde huzur ile dinlenmelerini sağlayan rekreasyonel hizmetler sunmaktadır. Çünkü bu sesler ziyaretçiler üzerinde doğayı çağrıştırıcı olumlu etkiler bırakmaktadır. Bu kapsamda mekanlardaki rahatsız edici ve istenmeyen seslerin uzaklaştırılması gerekmektedir. Araştırmada, kentin yoğun stresli ve gürültülü ortamından yine kent içinde tasarlanan su odaklı bir rekreasyon alanına davet edecek bir yaklaşım benimsenmiştir. Bu kapsamda rekreasyon alanlarında arka plan sesi olarak akarsuyun sesi, kuş sesi ve rüzgar ile oluşan ağaçların yaprak sesi ile akustik konforun belirlenmesi amaçlanmıştır. Çünkü bu sesler ziyaretçiler üzerinde doğayı çağrıştırıcı olumlu etkiler bırakmaktadır. Bu amaçla işitsel peyzaja yönelik akustik konfor önerileri sunan dünya örnekleri araştırılmış ve çalışma alanında akustik konfor sağlayabilecek doğal seslerin çalışma alanına getirilmesine yönelik doğal ve/veya yapay tasarım önerileri getirilmiştir.

Nüfus yoğunluğu ve trafik yoğunluğundaki artışa paralel olarak artan gürültü kirliliği doğal ve/veya yapay peyzaj elemanları kullanılarak yaşanabilir bir seviyeye düşürülmesi mümkündür. Kentlerde doğal güzelliklerini hala koruyan dere gibi su yüzeyleri ve çevrelerinin kullanım yoğunluğu dikkate alındığında 
bu alanlarda gürültünün tanımlanması, kontrol edilmesi ve ses ölçümlerinin normal seviyeler düşürülmesi kentliye fiziksel, fizyolojik ve psikolojik olarak olumlu katkılar sağlayabilecektir.

Türkiye'nin ÇGDY Yönetmeliği gereği ilgili kamu kurum ve kuruluşların katıldığı yönetim organizasyonun kurulması ve gürültü kontrolü ile ilgili gerekli denetim ve izleme programını oluşturması gerekmektedir. Dolayısı ile mekansal planlama ve peyzaj planlama sürecinde nazım imar planı, uygulama imar planı ve doğa koruma planları gibi planlar hazırlanırken ulusal bölgesel ve yerel ölçekte gürültü haritalarının hazırlanması önem taşımaktadır.

\section{Teşekkür ve Bilgi Notu}

Desteklerinden dolayı Bursa Teknik Üniversitesi, Bilimsel Araştırma Projeleri Birimine teşekkür ederiz.

Destek Bilgisi: Bu çalışma Bursa Teknik Üniversitesinde yürütülen 211N023 numaralı Bilimsel Araştırma Projesi kapsamında üretilmiştir.

Etik Onayı: Makalede ulusal ve uluslararası araştırma ve yayın etiğine uyulduğunu yazarlar beyan eder. Aksi bir durumun tespiti halinde GSI Journals Serie A: Advancements in Tourism Recreation and Sports Sciences Dergisinin hiçbir sorumluluğu olmayıp, tüm sorumluluk makale yazarlarına aittir.

Etik Kurul Onayı: Bu çalışma, TR Dizin etik kurul izni gerektiren çalışma grubunda yer almamaktadır.

Çıkar Çatışması: Makalede herhangi bir çıkar çatışması ya da kazancı yoktur.

Araştırmacıların Katkı Oranı: Çalışma üç yazarın katkısı ile hazırlanmıştır. Katkı oranları: 1. Yazar=\%50, 2. Yazar $=\% 45,3$. Yazar $=\% 5$

\section{Kaynaklar}

Ağaçsapan, B. \& Çabuk, A. (2019). Sustainable Aviation: GIS For Airport. GSI Journals Serie B: Advancements in Business and Economics, 2(1), 26-34.

Archello. (2021). Highway Noise Barrier. Erişim Adresi (02.12.2021): https://archello.com/project/highway-noise-barrier

Architects, H. L. (2016). Land Art Park Buitenschot (Amsterdam): Un parque para la reducción de la contaminación acústica. Planur-e: territorio, urbanismo, paisaje, sostenibilidad y diseño urbano, (8): 17.

Armato, F. (2017). Pocket park: Product urban design. The Design Journal, 20(sup1): 1869-S1878.

Aslan, F., Mustan Dönmez, B. \& Yılmaz, B. (2014). Görsel ve işitsel sanatların doğa ile olan köprüsü: Peyzaj mimarlığı. İnönü Üniversitesi Sanat ve Tasarım Dergisi. (2014). Cilt:4, Sayı:9, 99-106.

Bao, Z. \& Lu, W. (2021). A decision-support framework for planning construction waste recycling: A case study of Shenzhen, China. Journal of Cleaner Production, 309: 127449.

Bayraktar, Ş. (2006). İzmit kent merkezinin gürültü kirliliği. Yayınlanmamış Yüksek Lisans Tezi, Kocaeli Üniversitesi: Fen Bilimleri Enstitüsü.

Bayramoğlu, E., Özdemir, B. \& Demirel, Ö. (2014). Gürültü Kirliliğinin Kent Parklarına Etkisi ve Çözüm Önerileri: Trabzon Kenti Örneği. İnönü Üniversitesi Sanat ve Tasarım Dergisi, 4 (9), 35-42.

Berkers, M. (2016). Transforming the Green. Technical and cultural fusion: The Buitenschot Park in Amsterdam. Topos: European landscape magazine, (97), 90.

Brown, A. L. (2011). Advancing the concepts of soundscapes and soundscape planning. In Proceedings of the Conference of the Australian Acoustical Society. Pp. 1-11. 
Eşbah H. O., Demir, S., \& Yıldırım Y. (2022). Akarsu Koridorlarında Akustik Konforun Değerlendirilmesinde İşitsel Peyzajın Rolü, Ayvalı Dere Örneği. GSI Journals Serie A: Advancements in Tourism, Recreation and Sports Sciences (ATRSS), 5 (1): $27-43$

Cerwén, G. (2018). On the Intersection Between Speaker Installations and Urban Environments. MultiObjective Optimization of Industrial Power Generation Systems; IGI Global: Hershey, PA, USA, 2345.

Cerwén, G. \& Mossberg, F. (2019). Implementation of quiet areas in Sweden. International journal of environmental research and public health, 16(1), 134.

Chiesura, A. (2004). The Role of Urban Parks for the Sustainable City. Landscape and Urban Planning 68, 129-138.

Claus, C. \& Pak, B. (2018). Towards Urban Sound Design for Transitional Public Railway Park/Places: Sonic Strategies for Engagement, Critical and Spatial Design. In CA2RE: Conference For Artistic and Architectural (Doctoral) Research Proceedings. (pp. 108-119). Aarhus School of Architecture; Aarhus.

Demirkale, S.Y. \& Aşcıgil, M. 2007. Sağlıklı kentlerle ve yapılarla ilgili Türkiye'nin gürültü politikası. VIII. Ulusal Tesisat Mühendisliği Kongresi, İzmir, 267-285.

Denić-Jukić, V. (2019). Hydrology and physical limnology in Croatia. Geofizika, 36(2), 185-194.

Emilson, L., Friman, M. \& Engström, N. (2020). Efterklang Project Report. Erişim tarihi (24.11.2021): https://omvarldsbevakning.byggtjanst.se/contentassets/fac9003e386e445392e7bfac66b461a5/rappor t-ljudmatning-av-ljudmuren.pdf

Girot C., 2016. Landscape Topology. Theory lab lecture series: ILA Institute of Landscape Architecture. Erişim Tarihi (02.12.2021): content/uploads/2016/04/V05FS16_Handout.pdf

Han, X., Huang, X., Liang, H., Ma, S. \& Gong, J. (2018). Analysis of the relationships between environmental noise and urban morphology. Environmental pollution, 233, 755-763.

Hedfors, P. (2003). Sonic tools for landscape architecture. In Conf. proceedings "Acoustic Ecology", Australian Forum for Acoustic Ecology/World Forum for Acoustic Ecology, Melbourne, Australia, pp. 19-23.

Hiramatsu, K. (2006). A Review of Soundscape Studies in Japan. Acta Acustica United with Acustica, 92, (6), 857-864.

Kang, J. (2011). Urban soundscape: from research to practice. In Local Authority Noise Action Forum group, University of Sheffield, UK, 212-213.

Kaymaz, I., Belkayalı, N. \& Akpınar, N. (2013). Peyzaj Mimarlığı kapsamında işitsel peyzaj kavramı: Ankara kent parkları örneği. Peyzaj Mimarlığı, 5. Kongresi, 182-194.

KGM (2020). Trafik ve Ulaşım Bilgileri. Otoyollar ve Devlet Yollarının Trafik Dilimlerine Göre Yillık Ortalama Günlük Trafik Değerleri ve Ulaşım Bilgileri. Erişim Adresi (10.02.2022): https://www.kgm.gov.tr/SiteCollectionDocuments/KGMdocuments/Istatistikler/TrafikveUlasimBil gileri/20TrafikUlasimBilgileri.pdf, 165-176.

Labuz, R. (2019). Pocket Park-A New Type of Green Public Space in Kraków (Poland). In IOP Conference Series: Materials Science and Engineering. 471 (11): 112018, IOP Publishing.

Landezine. (2016). Buitenschot Park. Erişim Adresi (02.12.2021): https://landezine.com/buitenschot-parkby-hns-landscape-architects/

Mancini, S., Mascolo, A., Graziuso, G. \& Guarnaccia, C. (2021). Soundwalk, Questionnaires and Noise Measurements in a University Campus: A Soundscape Study. Sustainability, 13(2), 841. 
Eşbah H. O., Demir, S., \& Yıldırım Y. (2022). Akarsu Koridorlarında Akustik Konforun Değerlendirilmesinde İşitsel Peyzajın Rolü, Ayvalı Dere Örneği. GSI Journals Serie A: Advancements in Tourism, Recreation and Sports Sciences (ATRSS), 5 (1): 27-43

Oberman, T., Jambrošic, K., Aletta, F. \& Kang, J. (2019). Towards a soundscape surround index. In Proceedings of the International Congress on Acoustics (pp. 829-835). International Congress on Acoustics.

Oberman, T., Jambrošić, K., Horvat, M. \& Bojanić Obad Šćitaroci, B. (2020). Using virtual soundwalk approach for assessing sound art soundscape interventions in public spaces. Applied Sciences, 10(6), 2102, 1-27.

Oddmusic. (2021). Odd Music Project. Erişim Adresi http://www.oddmusic.com/gallery/om24550.html

Omvarldsbevakning. (2020) Omvarld Bevakning Efterklang Project. Erişim Adresi (01.12.2021): https://omvarldsbevakning.byggtjanst.se/contentassets/fac9003e386e445392e7bfac66b461a5/rappor t-ljudmatning-av-ljudmuren.pdf

Osvalder, A. L. \& Nybacka, M. (2018). Different user groups' perception, experience and need of spoken information in public transportation spaces. In International Conference on Applied Human Factors and Ergonomics, pp. 26-38. Springer, Cham.

Özçevik, A. \& Can Z.Y. (2011). Soundscape and the Adaptation of Soundscape to Covered Spaces. Megaron. 2011; 6(1), 52-59.

Özdemir, B.; Bayramoğlu, E. \& Demirel, O. (2014). Noise Pollution and Human Health in Trabzon Parks. Stud. Ethno Med. 8, 127-134.

Pouya, S. (2017). The role of landscape architecture on soundscape experience. Turkish Journal of Forest Science, 1(2), 183-193.

Radicchi, A., Cevikayak Yelmi, P., Chung, A., Jordan, P., Stewart, S., Tsaligopoulos, A., ... \& Grant, M. (2021). Sound and the healthy city. Cities ve Health, 5(1-2), 1-13.

Ramsar (1994). Özellikle Su Kuşları Yaşama Ortamı Olarak Uluslararası Öneme Sahip Sulak Alanlar Hakkında Sözleşme: Ramsar Sözlemesi. Yürürlük: 13 Kasım 1994. Erişim Tarihi (01.02.2021): https://teftis.ktb.gov.tr/TR-263672/ozellikle-su-kuslari-yasama-ortami-olarak-uluslararasi-.html.

Schafer, M. (1977). Our Sonic Environment and The Soundscape: The Tuning of The World, Destiny Books, Rochester, Vermont.

Schlüter, F. (2013). A Soundscape Remodelled. Erişim Adresi (01.12.2021): https://sonicagents.wordpress.com/2013/01/04/a-soundscape-re-modeled/

Schulte-Fortkamp, B. \& Brooks, B. (2018). Urban planning integrating the soundscape approach. In INTER-NOISE and NOISE-CON Congress and Conference Proceedings (Vol. 258, No. 4, pp. 35513556). Institute of Noise Control Engineering

Soundscapedesign. (2021). Soundscape Design, Listen to City. Erişim Adresi (02.12.2021): https://soundscapedesign.info/category/projects/

Stevens, M. (2010). Quietening open spaces towards sustainable soundscapes for the City of London. Report to the Environmental Protection UK.

Tülek, B. \& Barış, M. E. (2014). Kent içi ve yakın çevresindeki su kıyısı rekreasyon alanlarının ekolojik kriterler açısından değerlendirilmesi: Mavi Göl örneği. Uludağ Üniversitesi Ziraat Fakültesi Dergisi, 28(2), 13-26.

Urbanidentity. (2021). Urban İdentity, Sheaf Square. Erişim Adresi (02.12.2021): https://urbanidentity.info/projects/sheffield_sheaf_square/

WHO (1999). World Health Organization Occupational and Environmental Health Team.Guidelines for community noise. World Health Organization. https://apps.who.int/iris/handle/10665/66217 
Eşbah H. O., Demir, S., \& Yıldırım Y. (2022). Akarsu Koridorlarında Akustik Konforun Değerlendirilmesinde İşitsel Peyzajın Rolü, Ayvalı Dere Örneği. GSI Journals Serie A: Advancements in Tourism, Recreation and Sports Sciences (ATRSS), 5 (1): 27-43

WLA, 2021. World Landscape Architecture. Erişim Tarihi (24.11.2021): https://worldlandscapearchitect.com/buitenschot-park-haarlemmermeer-the-netherlands-hnslandscape-architects/.

Xiao, J., Tait, M. \& Kang, J. (2017). Design with Fragrant Plants and Waterscapes. Designing with Smell: Practices, Techniques and Challenges.

Yildırım, Y. \& Arefi, M. 2020.The sound of New Urbanism. Journal of Urbanism: International Research on Placemaking and Urban Sustainability, 14(2), 165-184. 